\title{
STRENGTHENING LABOUR AND WELFARE INSTITUTIONS IN TIMES OF GLOBAL ECONOMIC CRISIS: EXPERIENCES AND LESSONS LEARNT
}

\author{
Falendra Kumar Sudan, Ph.D.*
}

\begin{abstract}
The present paper intends to examine the labour market scenario in the context of the global financial and economic crisis, social protection during crisis, responses to the economic crisis at different levels, and the lessons learnt to protect workers, families and societies from the negative repercussions of this crisis and in the future. The current global financial crisis has quickly spread from its origin in the United States to the global economy, resulting in collapsed aggregate demand and freezing of credit channels. Consequently, millions of workers around the globe have been laid off, or for those lucky enough to have held on to their jobs, many have experienced cuts in hours worked, wages and other benefits. Though there are increasing signs that the major economies are exiting recession, the weakness of the labour market will remain a key challenge for governments in the years to come, particularly in terms of vulnerable groups such as youth. Over the medium- and long-term, governments should also aim to develop a comprehensive and integrated policy and institutional framework that will enable them to better respond to crises, emanating from not only global shocks but also those arising from local and regional phenomena. This involves the development of labour market institutions and a broad-based social security system, which acts as an automatic stabilizer during a crisis. In developing countries, barriers to formalization need to be reduced to ensure that workers have more opportunities to find decent jobs and be protected by labour market institutions, including social protection measures. Finally, the policy response should be the outcome of constructive dialogue between the social partners.
\end{abstract}

Key words: Labour and Welfare Institutions, Strengthening, Global Economic Crisis, Experiences, Lessons.

\section{INTRODUCTION}

Institutions are the means through which national governments administer policies that seek to improve their citizens' lives. In the context of current global economic crisis, labour and welfare institutions matter even more. Governments face tremendous pressure to protect workers and their families against the negative repercussions of the economic downturn and to stabilize their economies. There is considerable variation between the labour and welfare institutions in developed and developing countries. The current global economic crisis highlights the need for all countries to help stabilize and rebalance the global economy. The global economic shocks have resulted in credit

* Mr. Sudan is Associate Professor, Department of Economics, University of Jammu, Jammu and Kashmir, India 180 006.E-mail:fk_sud@rediffmail.com 
squeeze, decline in trade and investment, and fall in remittances and uncertain aid flows to developing countries. These shocks are increasing inequalities and fueling insecurity in the developing countries. The developed countries are worried about perceived unfair trade practices and decline in domestic economic growth and fueling protectionist pressures. The return to sustained economic growth is contingent upon collectively restoring consumer confidence, restoring regulated free trade and avoiding protectionism, as well as countering the negative labour market effects of the crisis in developed and developing countries alike. Thus, there is need to strengthen the labour and welfare institutions in developing countries with support of developed countries to stabilize and structurally rebalance the global economy. With above backdrop, the present paper intends to examine the labour market scenario in the context of the global financial and economic crisis, social protection during crisis, responses to the economic crisis at different levels, and the lessons learnt to protect workers, families and societies from the negative repercussions of this crisis and in the future.

\section{Economic Crisis and Labour Market Scenario}

The global economy is experiencing the worst economic crisis since the Great Depression. Certain sectors are being disproportionately affected by the crisis. The effects on financial services and construction have been immediate and profound (Escudero, 2009). In a second round, sectors like automobile production were most affected by the credit squeeze. The export-oriented activities, tourism and commodity sectors are now suffering from rapidly falling world demand and declining prices. The impact on developing economies that rely heavily on a narrow, commodity-based export sector is dramatic. In 2007 and 2008, world output grew by over 5 percent and 3.4 percent respectively. After contracting by about 1 percent in 2009, global activity is forecast to expand by about 3 percent in 2010, which is well below the rates achieved before the crisis (IMF, 2009a). As growth rates declined in 2008, the effects on the labour market started to be felt. After four years of consecutive declines, the global unemployment rate increased to 6 per cent in 2008, up from 5.7 per cent in 2007, and the number of unemployed rose by 11 million (ILO, 2009a). The impact was immediate and particularly severe in the United States, where employment losses started in early 2008 and have continued to mount since. Similar trends are present in Japan. In European countries, job losses have been contained to some extent due to recourse to shorter hours or partial unemployment benefits. However, even there, recent indicators suggest significant increases in unemployment.

ILO (2009a) estimates that 6.0 percent of the world's workers were out of work and looking for employment in 2008, up from 5.7 percent in 2007. ILO (2009b) suggests that in 2009 between 210 million and 239 million people will be unemployed and corresponds to global unemployment rates of 6.5 and 7.4 percent, respectively. Due to the impact of the crisis, women continue to find themselves in a disadvantaged position as compared to their male counterparts in labour markets around the world (ILO, 2009c). The youth unemployment rate rose by 0.4 percentage points in 2008, 
bringing the number of total unemployed youth around the world to 76 million (ILO, 2009a), which is projected to increase from 12.2 percent in 2008 to between 13.0 and 15.1 percent in 2009 (ILO, 2009b). The credit squeeze in developed countries, coupled with slowing growth rates, is fueling a rise in unemployment. ILO (2009b) projects that developed economies and the European Union will likely account for 35 percent to 40 percent of the total global increase in unemployment in 2009, although this region makes up less than 16 percent of the global labour force. The developed economies, including the European Union and parts of East Asia, where the gender gaps in employment opportunities before the onset of the crisis were smaller, male and female unemployment rates may converge because of a greater impact of the crisis on male unemployment rates (ILO, 2009c). Youth employment is projected to increase between 2.9 and 5.6 percentage points in developed economies and the European Union (ILO, $2009 \mathrm{~b})$. In many developing countries that rely on investment and trade for growth, a decline in trade flows and investment flows comes with negative repercussions.

About one third of growth in emerging countries is derived from investment; therefore, the precipitous decline in capital flows and investment has serious consequences for development (ILO, 2008a). The projections suggest that private capital flows to emerging countries are likely to fall to $\$ 165$ billion in 2009 from $\$ 929$ billion in 2007 (ILO, 2009d). The falling trade is a major conduit that is adversely affecting the labour market, particularly the labour-intensive manufacturing sectors in developing countries. The lower demand, slowed production and restricted access to trade financing have contributed to a major recent contraction in global trade. The world trade is forecast to decline by approximately 9 percent in 2009, the biggest contraction since World War II (WTO, 2009). And as leaders face pressure to explain mounting job losses, some are inching towards protectionism. Falling exports are severely effecting economies around the world, especially some Asian and Latin American economies that rely on export-led growth. During the last quarter of 2008, employment in eight export-oriented sectors in India (mining, textile and textile garments, metals and metal products, automobile, gems and jewellery, construction, transport and information technology) fell by over 3 per cent (Chandrasekhar and Ghosh, 2009). The South African economy may lose a quarter of a million jobs as a result of the crisis and this is likely to undermine government plans to cut the unemployment rate to 14 per cent by 2014 (Seria and Cohen, 2009).

In developing countries, shuttered factories and companies, especially in labourintensive manufacturing, have caused many to loose their jobs. This decline in wage employment in the formal economy is likely to fuel the growth of the informal economy and informal employment, with precarious contracts and the potential for labour exploitation including child labour (ILO, 2009e). In addition, there will likely be some reverse migration from urban areas back to rural areas. In these countries, job losses will exacerbate challenges of employment informality and working poverty. In the absence of income support alternatives, job losers either move back to rural areas 
or take up informal jobs in the urban economy (Betcherman and Inslam, 2001). For instance, a reversal in rural-to-urban migration flows has been noted in China and, in Africa, workers who had formal jobs in export oriented sectors have been pushed to the informal economy where they will earn lower wages. As a result, between 40 and 50 per cent of the world's working men and women in 2009 are not expected to earn enough to lift themselves and their families above the $\$ 2$ a day per person poverty line (ILO, 2009a).

Agriculture continues to be the predominant sector in rural areas. The low productivity work in agriculture is common, which means the sector is already saturated and may not be able to provide productive work for those returning from urban areas. Underemployment could be the result. Women in developing countries, who comprise a significant share of employment in labour-intensive manufacturing industries, are facing significant negative repercussions in the face of the current crisis. Even prior to the crisis, women faced significant barriers to accessing decent employment opportunities in several developing countries; they tended to be disproportionately represented in temporary employment, and other forms of precarious work, and this will only be exacerbated amid the economic crisis. A similar story applies to youth in developing countries. As companies and factories lay off employees, the less experienced young workers are more likely to be let go of, even as new cohorts enter the labour market. As firms and factories shed jobs lying off migrant workers, remittances too are seeing a decline at the same time that the uncertainty in aid flows is growing. For a number of developing economies, remittances are an important source of external financing and income. In some countries, remittances can constitute as much as 24 percent of gross domestic product; in more than 20 countries, they constitute over 10 percent of GDP (World Bank, 2009a).

As such, falling remittances carry major implications for several developing countries and the households within them that have come to rely on remittances as a source of income. This fall in remittances also comes at a time when unstable economic conditions are fueling uncertainly in the flows of development aid. The transmission of the crisis through these channels has therefore led to severe labour market effects that are causing real pain to workers and their families in developed and developing countries. These negative pressures on the global economy and labour markets continue to dominate despite the upward pull of monetary and fiscal policy measures that many governments have instituted since the beginning of the crisis (IMF, 2009b). This reinforces the case for strong and stable labour and welfare institutions that can improve the resilience of economies through this crisis, but that are also firmly in place to restrain the impact of future crises.

\section{Social Protection During Economic Crisis}

Social protection, if well designed, plays a crucial role in alleviating social hardship in the face of the crisis. Yet, the array of benefits and support measures available to 
individuals varies significantly across countries and regions. Social spending as a share of GDP ranges from as high as 14 percent in advanced economies to as low as 2 to 3 per cent in Asia, the Middle East and sub-Saharan Africa. The reality is that in many emerging and developing countries, the majority of workers do not contribute to basic social security coverage, including unemployment benefits. This is due mainly to the fact that most employment is in the informal economy. It is important to note that in many countries - emerging, developing and developed - unemployed workers often have access to other benefits and support (e.g. social assistance, training, etc.). Even where unemployment benefit systems exist in emerging and developing economies, they are often restricted to urban areas. For example, in China, close to 5 million unemployed urban workers (57 per cent) were without unemployment insurance in 2005. Given that over 60 per cent of total employment in China is in rural areas, the share of unemployed workers unable to access unemployment benefits is probably closer to 84 per cent. In many developed countries, job losers are often not eligible for unemployment benefits. In half of the OECD member countries, 50 per cent or more of the unemployed do not receive unemployment benefits (though non-recipients may be entitled to social assistance benefits). Even in countries like France and the United Kingdom, where coverage is greater, many workers do not receive unemployment benefits.

Social expenditures (consolidated central government) are defined as transfers to protect the entire population against certain social risks such as medical services, unemployment compensation, social security pensions, and social assistance benefits. Social security benefits include sickness and invalidity benefits, maternity allowances, children's or family allowances, unemployment benefits, retirement and survivors' pensions, and death benefits. Subsidies, grants, and other social benefits include all unrequited, non repayable transfers on current account to private and public enterprises; grants to foreign governments, international organizations, and other government units; and social security, social assistance benefits, and employer social benefits in cash and in kind.

In Canada, Japan, and the United States, where regulations governing access to such benefits are often much stricter, the share of unemployed workers not receiving benefits can be well over half. As of January 2009, more than 6 million jobless Americans were not receiving unemployment insurance. In Japan, about 77 per cent of unemployed persons do not receive unemployment benefits. The absence of unemployment benefit support is made worse by the fact that for many individuals social protection is conditional on being employed. The immediate fall in income resulting from unemployment is thus worsened by the loss in non-cash benefits such as employer-sponsored health. The loss of these benefits can be a particularly severe blow to middle- and low-income households.

An immediate consequence of the collapse of stock markets in 2008 has been the dramatic decline in individual wealth held in pensions. Between January and October 
of 2008, private pensions registered losses of nearly 20 per cent - representing a value of $\$ 4.5$ trillion. This has prompted concerns about the adequacy of retirement savings for many individuals. The generosity and replacement rates of unemployment benefits - an important consideration - vary significantly from country to country, and should not be taken as an indication as to the amount of money spent on non-work assistance. In World Bank client countries with funded pension systems, losses in pension funds range from 8 per cent to 50 per cent (World Bank, 2009b). In Chile, for example, the private pension funds that cover 8.3 million workers lost a total of \$25 billion in 2008 . Traditional pension systems provided by governments on a pay-as-you-go basis will also be affected by the current downturn, but much less than private pension funds. Interestingly, in view of the pension crisis, the World Bank has shifted its stance on this matter and is now advocating greater focus on government-backed pay-as-you-go systems (World Bank, 2009b).

\section{RESPONSES TO THE CRISIS}

Given the grim economic scenario and risk of widespread labour market and social consequences, countries around the world have adopted unprecedented measures to address labour problems in the context of the current global economic slowdown.

\section{a. International Efforts}

The global financial market has been unstable since as early as 2007. But 2008, marked by bankruptcies and bailouts of financial institutions (notably AIG, Bears Stearns and Lehman Brothers) placed the financial system in a state of constant turmoil and volatility. The credit markets froze and stock indices tumbled throughout 2008. The first round responses were largely uncoordinated, but the case for more internationally coordinated action has become increasingly clear - as witnessed by several efforts. These include: (a) G20 commitment in key determinants of decent work and agrees on the importance of coordinating macro-economic policies and reducing global imbalances; (b) Economic Recovery Plan approved by the European Council in 2008 (200 billion euros) to boost demand through joint fiscal stimulus action as well as temporary support for the unemployed through cash transfers and extension of unemployment benefits; (c) ILO's Social Justice Declaration stresses that "As trade and financial policy both affect employment, it is the ILO's role to evaluate those employment effects to achieve its aim of placing employment at the heart of economic policies" (Khatiwada, 2009); (d) IMF has provided financial assistance to countries affected by rapidly declining capital inflows, and balance of payments deficits.

\section{b. Government Efforts}

Government efforts to strengthen bank balance sheets were initially undertaken on a case by- case basis. For example, the United States and European governments injected capital into individual banks or induced mergers in hopes of reviving the credit market by encouraging banks to lend to one another. But market confidence continued to decline and credit markets remained frozen, highlighting the need for 
system-wide intervention. The system-wide interventions subsequently put in place by the United States and European governments have involved ensuring bank funding through explicit government guarantees on retail deposits and other bank liabilities, and reducing bank leverage through government purchases of distressed assets or capital injections. Almost all the major economies have increased guarantees of private deposits, put in place inter-bank loan guarantees, banned or restricted short-selling and injected capital into troubled banks by buying equity stakes.

\section{c. Social Dialogue Initiatives}

In the early stages of the crisis, social partners in many countries had limited involvement in the design and implementation of government anti-crisis measures (Rychly, 2009). More recently, in some cases, social dialogue has been at the heart of governments' plan to address the economic slowdown. The action has been swift, but relatively misaligned. There has been considerable emphasis on rescuing the financial sector. The amount spent on financial rescue efforts far surpasses fiscal rescue efforts for all countries except the United States. Indeed, protecting banks' solvency and restoring the availability of credit to enterprises and households was rightly regarded as a pre-condition to avoid a total collapse of the financial system, with unpredictable consequences for the real economy. Governments have also announced fiscal stimulus measures - an important step in the right direction. But there is much debate regarding the desirable content of the packages, their timing, and whether some of the measures should be merely temporary - as championed by the " $3 \mathrm{t}$ " approach - or rather, more enduring.

\section{LESSONS LEARNT}

The global economic crisis comes after a sustained period of growth, whose benefits were unevenly shared (ILO, 2008b). During the two decades that preceded the crisis, the incomes of richer groups grew faster than those of middle- and low-income groups. The growing income inequalities within countries contributed to an increase in the demand for credit, which, in conjunction with poor financial regulation, lies at the heart of the current crisis. By definition, any financial crisis has serious consequences on the entire real economy, which depends so vitally on financial markets in order to grow and create jobs. But the current financial crisis is deeper than recent ones. It has its origins in developed countries which had been the engine of global demand and trade growth. In addition, given the strong international inter-linkages, it affects most countries. And, against the backdrop of the pre-crisis expansionary period, in which gains were unevenly shared, the economic and social costs of the crisis are noticeably widespread. Perceptions of unfairness are mounting, increasing the risk of social instability. The challenge is to avoid a major labour market and social crisis. Already, job losses have mounted and new entrants like youth have had difficulty finding employment. However, the rise in unemployment has been contained to some extent as firms have attempted to limit the extent of layoffs via recourse to shorter hours and partial unemployment. This could change with a prolonged recession - in such an 
event, significant increases in unemployment would be unavoidable and, in developing countries, a long-lasting shift to informality and higher working-poverty would occur. A prolonged recession would have deeper effects than just higher unemployment and increased informality and working-poverty. With so many people around the world lacking social protection, social hardship resulting from poor job prospects would intensify. Some developing countries will also need to integrate growing numbers of return migrant workers. And within countries the movement of workers from urban centres where jobs disappear, back to rural areas poses acute challenges as well. Social protection itself is being affected by the crisis, at the time when it is most needed, especially in countries that relied excessively on private pension funds or employerprovided health care.

\section{A Global Jobs Pact}

A global jobs pact would be instrumental in overcoming the crisis and paving the way for a more sustainable economy. A global approach is needed because the measures, to be effective, need to be coordinated across countries. The emphasis on jobs comes from the realization that decent work is central to reactivating the economy in a sustainable manner. Measures are best implemented through social dialogue at the national level, but greater cooperation at the international level can also have mutually reinforcing benefits - thus the need for a pact. In this respect, building upon the lessons of the past and avoiding counter-productive measures, such as trade protectionism and generalized wage deflation, will also prove invaluable.

\section{Employment Guarantee Programmes}

Employment guarantees are another employment-intensive measure which, as experience from earlier crises shows, can be especially cost-effective in the face of the crisis - if well-designed and targeted (Márquez, 2000; Cook, 2008). Argentina's Jefes y Jefas de Hogar Desocupados programme, introduced during the 2001 crisis, reduced aggregate unemployment by an estimated 2.5 percentage points, increased labour force participation and reduced extreme poverty (Galasso and Ravallion, 2004). Similar public works programmes in Indonesia, Republic of Korea and Thailand adopted after the East Asian financial crisis, proved to be relatively successful in employing large numbers of individuals. However, studies suggest that programmes could have been more effective if better designed and monitored (Betcherman and Islam, 2001). The National Rural Employment Guarantee (NREG) of India provides an important safety net for many rural households. The programme aims to provide additional employment to the underemployed and the unemployed by entitling every rural Indian household to 100 days of work per year (Chakraborty, 2007). Active labour market programmes play an important role in skills development and more broadly in facilitating the adjustment of individuals to changing labour market conditions. Such programmes can take many forms, including: job-search assistance and monitoring, personalized action plans for jobseekers, training, and targeted programs for disadvantaged groups. They can also provide much needed income support. If properly designed, 
they can enhance employability and improve labour market mobility in the short term. They can further facilitate matches between the skills of displaced workers and the skills required in the jobs created by new public investment (e.g. in construction, infrastructure and alternative energy).

III. Enhancing Public Employment Services and Active Labour Market Programmes Some lessons learned to date about enhancing the effectiveness of active labour market programmes include: an obligation on the part of the benefit recipient to undertake an activity and enforcement of this obligation by the programme; making participation in programmes compulsory; targeting increased effectiveness of outcomes, programmes and services (e.g. combining training and job-search assistance); and in-work benefits help facilitate a return to work (Rosholm and Svarer, 2004; White and Riley, 2002). During a crisis, special programmes to assist displaced or retrenched workers should be intensified. Schemes targeting temporarily laid-off workers can be very efficient, since workers with firm-specific training are often expected to return to work at the same firm (or sector) when the business climate improves. This type of programme could complement the employment-intensive public investments and initiatives to extend, or enhance, unemployment benefit coverage. This may mean allocating additional resources to public employment services.

\section{Enhancing Social Protection, Especially Among Low-income Groups}

As the crisis unfolds, the risks that individuals around the world are facing are exacerbated by limited access to social security schemes and social safety nets. One way to provide assistance to individuals is to widen eligibility conditions and increase benefit amounts of existing social security schemes, e.g. by extending the duration or increasing the generosity of unemployment benefits. In the absence of existing schemes, however, it may be necessary to introduce new measures to help low-income and other vulnerable groups. For example, income support measures such as conditional cash transfers could be further strengthened (or introduced) to enhance human capital and access to education and health services, especially for the poor. This is particularly relevant given that in many low-income countries, crises are associated with poorer health and education outcomes for children, while in middle-income countries; they are associated with poorer health outcomes. Investments in children's education and health services also have a long-term systemic impact on poverty levels. Social and care services also provide job opportunities for women who may not be able to take up construction work on infrastructure projects.

\section{Conditional Cash Transfers}

Conditional cash transfers provide cash to poor families linked to certain educational and health-related conditions. The most common conditions focus on children's school attendance, health care check-ups and nutrition. One-third of developing countries have implemented some kind of cash transfer programmes. Conditional cash transfers have been effective at smoothing recipients' consumption during times of crisis. For 
example: (a) In Nicaragua, during the Central American coffee crisis, they smoothed consumption, protected children's school enrolment, reduced child labour and improved health outcomes; (b) Similarly, in Honduras, they allowed families to keep their children in school during the crisis; (c) They were also successfully introduced as part of earlier crisis responses in Colombia and Turkey; (d) Indonesia's scholarship and school subsidy programme was introduced in 1998 as a part of the Government's crisis response (Ginneken, 2005; Handa and Davis, 2006; Rawlings and Rubio, 2005; Sparrow, 2007).

While the above measures to protect the most vulnerable are important steps to addressing current challenges, they should form part of a systematic effort to develop a broad-based social security system (covering social assistance, education, health, unemployment benefits, etc.) and an overall poverty reduction strategy. Experience in several European and, more recently, some Asian countries has shown that a system of basic social security can mitigate the impacts of crises by means of automatic stabilizers - measures of support that automatically increase during times of crises or increased household vulnerability. Moreover, increases in social spending do not impede growth. On the contrary, if social protection is designed in a way that takes into account work incentives, it can boost the quality of growth through its pro-poor elements. For example, countries that have high social spending also tend to have lower levels of poverty and inequality. In other words, social security measures should, and can, be designed in such a way as to go hand in hand with economic policy to increase production, social protection and redistribution while addressing broader social issues such as family, care and poverty.

\section{Protecting the Rights of Workers}

In attempting to address the challenges associated with the crisis, it is crucial to ensure that workers rights and international labour standards are not compromised in the process. In fact, the observance of fundamental principles and rights at work must be part of the solution to the crisis. Moreover, respect for fundamental principles and rights at work are necessary to maintain social justice and peace, and to avoid political unrest which could create even greater delays in terms of a recovery. Some argue that labour market rigidity and overly stringent labour standards restrict the capacity of an economy to cope with economic shocks and that labour market flexibility can temper both the depth and duration of unemployment in the current crisis. However, there is considerable evidence drawn from cross-country studies that illustrates that there is no clear relationship between fewer labour regulations and faster economic and employment growth. Efforts that are focused exclusively on speeding up the labour market adjustment process to cope with the global economic crisis run the risk of impairing long-term growth potential. Maintaining labour standards helps support confidence and thus contributes to activating the economy. Moreover such measures would be equitable and enable vulnerable workers to deal with labour market risks, thus enhancing popular support for recovery packages. The crisis should be taken 
as an opportunity to reinforce the value of protecting and respecting workers rights. Measures should be taken to guarantee impartial and efficient judicial, as well as extrajudicial, proceedings dealing with individual and collective disputes.

VII. Social Dialogue and Collective Bargaining The social dialogue plays an essential role in the achievement of employment objectives and the improvement of social protection. Social dialogue can be instrumental in adopting effective, concrete policy responses by helping to improve the design of reforms, and it can help to bolster support for reforms in general. In Singapore measures were introduced to mitigate excessive layoffs, whereas in the Republic of Korea, eventual agreement improved the government's crisis-management capacity, and was instrumental in reaching national consensus (Campbell, 2001). In addition, Argentina's post recovery process was based on a social pact bringing all the social partners together. Social dialogue and collective bargaining are powerful tools to cope with immediate challenges of the crisis, such as preventing social unrest, avoiding damaging industrial actions, reducing income inequalities and maintaining social cohesion. Through improved governance social dialogue can also pave the way for shared prosperity and stability in the longer term. The role of collective bargaining and social dialogue will be critical to achieving a desirable outcome. Employers and workers need to be encouraged to participate in collectively negotiated wagesetting practices. Governments can help stimulate dialogue and facilitate concerned action to avoid socially undesirable, and potentially inefficient, generalized wage reductions. Moreover, collective bargaining can reduce overall wage inequality and ensures a stronger link between economic growth and average wages. Governments can support this process through minimum wage legislation, adjusted regularly to maintain the purchasing power and avoid sudden adjustments, which are detrimental to job creation.

\section{Improving Global Policy Coherence}

The need for greater global policy coherence has been emphasized many times, and for good reasons. But it is especially important now. Unless greater international coordination is achieved in the responses to the crisis, the world economy will face the prospect of a protracted economic crisis, entailing an even deeper labour market crisis and significant social hardship. No international organization or country has the mandate for, or is equipped to treat, all facets of the crisis and its underlying challenges. This is why the G20 has emerged as a key forum to discuss the crisis. The global crisis will not be solved by protectionist solutions. Rather, such solutions would depress world trade and investment, further aggravating the recession. Historical evidence from the Great Depression shows that attempts to restore economic stability by closing borders to trade are bound to fail and would generate even more substantial income and employment losses in the long-run. The repercussions for developing countries, which rely so heavily on world markets, would be especially acute. 


\section{Green Investments and Job Creation as a Response to the Crisis}

Globally, increased emphasis has been placed on investing in energy efficient technology for greener and more sustainable growth, and several governments have announced stimulus programmes designed to make progress in that regard. In some cases, the bulk of "greener" jobs created are likely, at least initially, to be in traditional sectors such as construction. Nevertheless, green investments should be viewed as an important step towards revitalizing the economy and generating more environmentally-friendly, decent work. And, in the medium to longer term, such investments can put countries on a path toward greener and more sustainable growth (Weiss and Kougentakis, 2009).

\section{Macroeconomic Stabilization in the Wake of Financial/economic Crisis}

Some countries are better-positioned than others. For example, those which took steps to better manage their economies and avoid excessive risk-taking and leverage are likely to be impacted less. Others are confronted with an array of challenges including limited fiscal space, a fragile current account, and potential runs on their currency. Indeed, countries inheriting large fiscal and current account deficits will be much more vulnerable, especially if these imbalances are driven by exogenous circumstances (most notably the need to cope with the terms of trade shock unleashed by the food and fuel price crisis of mid-2008). Circumscribing policy options of particular developing countries with a framework of conditionalities by international financial institutions will compound the difficulties faced by such countries (Planning Commission, 2008; Nasir, 2009; Kyloh and Saget 2009). Much of the fiscal tightening is expected to come through reduced expenditure on public sector wages and benefits, reductions in the overall level of social expenditure, revised indexation arrangements for social transfers, and a postponement of a planned increased in the minimum wage. These reforms imply a significant decline in the real value of pensions and other transfer payments, and a fall in real minimum wages. While it is important to restore the flow of credit to viable enterprises, the costly recapitalisation of the banks raises concerns, particularly when the opportunity cost is a substantial reduction in public expenditure on social security. What is needed is a counter-cyclical global mechanism, as advocated by some analysts (UNDESA, 2009). For instance, a global jobs fund would provide support to countries facing the global crisis.

\section{CONCLUSION}

In sum, the responses to the crisis should not just be seen as piecemeal measures to be rolled out temporarily, only to revert back to "business as usual" as soon as possible. The challenge now is to respond to the current crisis through measures, which pave the way for a better pattern of growth and development. Global coordination efforts currently underway could increase the propensity for multilateralism to tackle development challenges more creatively and effectively in the future. In this way, international partners can contribute to a better global economy and society, which, together with a new financial system, can form the foundation for more sustainable development. 


\section{References}

Betcherma, G. and R. Inslam (eds) (2001). East Asian labour markets and the economic crisis, World Bank.

Campbell, D. (2001). Social dialogue and labour market adjustment in East Asia after the crisis, in G. Betcherman, R. Islam, (eds): East Asian labour markets and the economic crisis: Impacts, responses and lessons, World Bank and ILO.

Chandrasekhar, C.P and J. Ghosh (2009). Asian face of the global recession, The Hindu Business Line, 10 February.

Chakraborty P. (2007). Implementation of the National Rural Employment Guarantee Act in India: Spatial Dimensions and Fiscal Implications, The Levy Economics Institute of Bard College, Working Paper No.505.

Cook, B. (2008). Active Labour Market Policies in the Neo-Liberal Era, Working Paper No. 08-03, Centre of Full Employment and Equity.

Escudero, V. (2009). Effects of the crisis on the financial sector: Trends and policy issues, Discussion Paper, IILS, ILO.

Galasso E. and M. Ravallion (2004). Social protection in a crisis: Argentina's plan Jefes y Jefas, in The World Bank Economic Review, 18(3): 367-399.

Ginneken, van W. (2005). Managing risk and minimizing vulnerability: The role of social protection in pro-poor growth, ILO.

Handa, S. and B. Davis (2006). The experience of conditional cash transfers in Latin America and the Caribbean, in Development Policy Review, Vol. 24, No. 5, pp. 513-536.

ILO (2008a). Social Security Policy Paper No. 3: Can Low-Income Countries Afford Basic Social Security? Geneva.

ILO (2008b). World of Work Report: Income inequalities in the age of financial globalization, IILS, Geneva.

ILO (2009a).Global Employment Trends, Geneva.

ILO (2009b). Global Employment Trends Update, Geneva.

ILO (2009c). Global Employment Trends for Women, Geneva.

ILO (2009d). The Financial and Economic Crisis: A Decent Work Response, In Institute of International Finance, Capital Flows to Emerging Market Economies, January.

ILO (2009e). The Fallout in Asia: Assessing Labour Market Impacts and National Policy Responses to the Global Financial Crisis, Geneva.

International Monetary Fund (IMF) (2009a). World Economic Outlook: Crisis and Recovery, Washington, D.C., October. 
IMF (2009b).World Economic Outlook April 2009, Washington, D.C.

Khatiwada, S. (2009). Stimulus packages to counter the global slowdown, IILS, ILO, Geneva.

Kyloh, R. and C. Saget (2009). A common crisis but contradictory responses: The European experience 2008/09, (Ukraine), ILO Policy Integration Department.

Márquez G. (2000). Labour Markets and Income Support: What Did We Learn From the Crises?, Working Paper No. 425, Inter-American Development Bank.

Nasir, Z.M. (2009). National policy responses to the financial and economic crisis, (mimeo), (Pakistan).

Planning Commission (2008).Economic stabilization with a human face, Report of the Panel of Economists, Government of Pakistan, October.

Rawlings, L. and G. Rubio (2005). Evaluating the impact of conditional cash transfer programs, The World Bank Research Observer, 20(1): 29-55.

Samans, R. (2008). Transitioning to a New U.S. International Economic Policy: Toward a 'Global Deal' to Revive and Broaden the Benefits of Growth, Washington, D.C.: Center for American Progress. 